\title{
Reading with the colonial in the life of Shaykh Musa Kamara, a Muslim scholar-saint
}

\author{
Wendell Marsh
}

\begin{abstract}
Introduction
The colonial-era Senegalese Muslim intellectual Shaykh Musa Kamara is best known for his over 1,700-page Arabic-language text about the history and social organization of the greater Western Sahel, Zuhūr al-basātīn fì tārīkh al-Sawädin (Flowers in the Gardens in the History of the Blacks) (Kamara 1998). Long celebrated by nationalist historiography as proof of an autochthonous historical consciousness and a spirit of tolerance, his status as a point of reference has been renewed in the contemporary context of Islamist political violence in the region. In particular, his invalidation of jihad as an acceptable practice makes Kamara relevant in new ways that enable the reconciliation of African racial identities and Islamic forms of life with global political modernity. However, these receptions do not account for Kamara's own intellectual project, nor do they exhaust the possible readings of him in the present. In addition to thinking about Senegal in terms that cohere with the modern, Kamara also offers a way of thinking about the Muslim-majority West African country, and the greater Western Sahel more generally, in terms that have emerged from the historical specificity of the region. These include saintly subjectivity, notions of power irreducible to either the religious or the political, and a method of genealogical criticism. Importantly, he developed these ideas at the moment when a consensus about the place of Islam in colonial governance was being elaborated: Sufi orders would mediate the relationship between the colonial state and the population, in which few were citizens and many were subjects. Revisiting his body of work permits us to consider an analytical language about an African society with deep histories of Islam and an intellectual elaboration that was expressed within and sought to intervene in a colonial context. By showing how Kamara has appeared alternatively as a wat̄ (Arabic: a friend of God or Muslim 'saint'), a colonial informant, a Senegalese historian, and most recently a Sufi scholar-saint, I highlight both the canonical status of his interventions and the difficulty of extracting him, and his knowledge production, from the coloniality of his moment or from more recent forms of domination.
\end{abstract}

\footnotetext{
Wendell Marsh is Assistant Professor of African American and African Studies at Rutgers University-Newark. His work interrogates the entanglements of Africa, Islam and modernity through the study of textual forms of knowledge. Email: wm276@newark.rutgers.edu

(C) International African Institute 2020. This is an Open Access article, distributed under the terms of the Creative Commons Attribution licence (http://creativecommons.org/licenses/by/4.0/), which permits unrestricted re-use, distribution, and reproduction in any medium, provided the original work is properly cited.
} 


\section{Biographical sketch}

Shaykh Musa Kamara was born around 1864 in the easternmost part of what was at the time Futa Toro, in the middle Senegal River valley. ${ }^{1}$ Futa Toro was an Islamic political formation established in 1776 by a movement, led first by Ceerno Sulayman Bal and then by Abdul Kader Kane, that had sought to limit the vulnerability to enslavement of a population with a deep Muslim past (Ware 2014: 110-62; Robinson 1975a; Barry 1998: 94-106). By the time of Kamara's birth, however, the autonomy of this agriculturally rich region had been compromised by French domination of the river-based trade in gum arabic and textiles, in addition to an emigration of the inhabitants of Futa to participate in the campaigns of the militant saintly figure Hajj Umar Tal, who had established a rather large Islamic political formation to the east and south (Robinson 1985; Hanson 1996: 141-55).

Kamara's family was a scholarly one. Accordingly, he pursued the traditional course of study, learning the Qur' an and the basics of Islamic law with nearby teachers. He showed early signs of being a gifted learner but maintained an independent disposition throughout the process. There seems to have been an important shift, however, when he began to travel in the early 1880s in pursuit of more advanced studies in Islamic jurisprudence, Arabic language and literature, and esoteric sciences. Taking up the common practice of seeking out knowledge from teachers wherever they may be found, Kamara travelled throughout his native Futa Toro, in the lands of the Bị̣̂ān tribes north of the Senegal River, and to Futa Jallon in the Guinea highlands further south. Through this process, he met and developed strong ties with Muslim scholars of the region, firmly integrating Kamara in the region's echelon of scholars. ${ }^{2}$ Hoping to take advantage of the networks of support and patronage that had criss-crossed and buttressed the region's political formations for at least the previous two centuries, Kamara made plans to go on the pilgrimage to Mecca, long a cherished but challenging accomplishment for West African Muslim scholars (Al-Naqar 1972). However, the difficulty of financing such a trip and the instability resulting from what would be the region's last jihad, waged by Mamadu Lamine Drame, limited his prospects for undertaking the hajj (Bathily 1970; Fisher 1970; Robinson 1975b). In the midst of the conquest of what would become French West Africa, Kamara settled down in the village of Ganguel with his entourage at around the age of thirty.

Although the following period of Kamara's life is less well documented, it has been ascertained that over the next thirty years Kamara developed a strong reputation as both a scholar and a planter in the eyes of his peers, catching the attention of the French surveillance apparatus. At this time, the French colonial state was heavily invested in surveilling Muslim scholars, worried that they constituted the most substantial threat to the colonial order. The responsible agency, the

\footnotetext{
${ }^{1}$ For a synthesis of Kamara's life, see Schmitz (1998) and Diop (2014). Other useful works include Bousbina (1992), Pondopoulo (1993), Hilliard (1977), Robinson (1998), Samb (1972) and Schmitz and Lo (2016).

${ }^{2}$ In two cases, these relations were cemented through marriage to the daughter or sister of a scholar. The theme of marriage and gender relations more broadly in the life and work of Kamara warrant further reflection, as Robinson has intimated (see Robinson 1988: 102).
} 
Service des Affaires Musulmanes, combined the textualist preoccupations of orientalist training with the practical demands of surveilling a population (Harrison 1988: 94-117; Burke 2014: 21-37). At this time, Kamara appeared as a useful interlocutor for the French for both orientalist and ethnographic reasons. The colonial administrator Robert Arnaud first recorded Kamara in 1912, mentioning him as the student of a trusted Muslim scholar and as someone who was critical of excesses of the maraboutic system; the French often assumed that the master-disciple relationship that structured so much of religious life in the region was an exploitative one. Kamara's independence, moderate influence without political ambition and familial connection to colonial employees made him attractive to colonial officials such as Arnaud (Pondopoulo 1993: 99-101). He developed a prolific correspondence with other officials who were interested in him as a source of information about the histories and customs of the region, which stimulated his writing endeavours.

It was under these conditions that Kamara undertook Zuhūr. From 1920 to 1926, Kamara travelled and recorded oral testimony about the region's past and accounts of various lineages, and consulted relevant texts. He focused on the history of Futa Toro, but situates it in Zuhūr within a broader regional history as well as a macro-history of Islam. As Pondopoulo has argued, Kamara anticipated remuneration for this lengthy undertaking and expected it to be published in a bilingual print edition. However, with a change of administrations and a rupture in the regime of colonial knowledge, the prospects for publishing Zuhūr began to disappear (Pondopoulo 1993: 109-10; Schmitz 1998: 32-51). The orientalist interest in textual knowledge, as represented by Kamara's work, was marginalized as ethnographic surveillance became the gold standard of colonial knowledge. Kamara began to pen much shorter topical works to add to his volumes on the legality of jihad and a text on Islamic law and legal customs of the Western Sahel (Kamara n.d.a; n.d.b; 2001; 2003; 2015).

Although Kamara's hopes for publication were dashed by broken promises, he bequeathed a number of his texts to the Institut Français d'Afrique Noire, where he has long been of interest to specialists of Islamologie, or francophone Orientalism, serving in many ways as the foundation of a Senegalese nationalist historiography. Kamara's descendants have been able to collect and identify more of his works, many thought to have been lost, as well as texts that belonged to him. Under the leadership of his grandson Thierno Mohammadu Bassirou Camara, ${ }^{3}$ an annual visit to Kamara's grave has been formalized and government support has been committed for a research centre and library.

\section{A subjectivist reading of Kamara}

The above account, presenting the academic consensus on Kamara's life, fails to exhaust the ways in which Kamara understood himself and how he has subsequently been received. For the project of understanding the twentieth-century

\footnotetext{
${ }^{3}$ This article reflects the variety of transcriptions of names in the region. I refer to historical figures using standardized Pulaar orthography, while with living people I use the spellings they use themselves.
} 
intellectual history of Senegal and identifying the problems encountered in thinking Africa beyond the colonial, other readings are needed, beginning with a reading of Kamara's own representation of himself. Kamara's 1937 autobiographical text, Tabshīr al-khā'if al-hayrān wa tadhkīruhu bisā at rahmat Allah al-Karim al-Mannān (The Spreading of the Good News of the Fearful and Confused and his Reminder of the Broadness of the Mercy of God, the Generous, the Bestower) (Kamara 2014), offers a guide to understanding Kamara in his own moment and to thinking about him in his own terms. ${ }^{4}$ Tabshīr makes an argument for Kamara's status as a wat̄, a friend of God or Muslim 'saint'. Tabshīr has often been used by academics to glean historical and religious facts about Kamara (Samb 1972: 107-28; Bousbina 1992). This section presents another approach, one that reads the text closely to think through Kamara's subjectivity, holding as much as possible the textual excess that is not contained by fact. This is what I call a subjectivist reading. ${ }^{5}$

There are some caveats to this approach. Kamara wrote Tabshìr in the twilight of his life, sometime between August 1937 and his death in 1945, following a series of disappointments and difficulties resulting from his being a colonial subject. ${ }^{6}$ The story that Kamara tells about himself at this moment, with its inclusions and exclusions, may or may not have been the story that he would have told at a different moment. All the same, a reading of Tabshīr affords us an indispensable account of the subjectivity of a Muslim scholar and saintly figure that was forged over much of the course of French colonization, granting us an opportunity to think through the entanglements of Islam, Africa and the colonial.

Tabshīr is a writing of the saintly self, charged with sentiment and spiritual striving. Such writing about the lives of friends of God is abundant in Islamic contexts, including in the greater Western Sahel. They appear under many names, including tarjama (biographical profile), manāqib (accounts of exemplary acts, hagiographic monographs), tadhkīra (notebooks and/or memoirs) and risāla (epistles). While there is a debate among scholars of Islam as to the extent to which writing on the lives of saintly figures can be treated coherently as a class, there is a shared tendency to refer to this literature as hagiography. ${ }^{7}$ These texts typically narrate episodes in the life of friends of God, plotting their sanctification and making an argument for their saintly status.

However, we should pause at the moment of translation that categorizes these sophisticated and diverse genres and traditions using terms such as hagiography, biography or autobiography. Given the difference between Kamara's language and our own, and between his time and ours, as well as the differing categories

\footnotetext{
${ }^{4}$ My reading of Tabshīr follows from the work of Abdul Malal Diop, a Senegalese Arabist who has written extensively on Kamara.

${ }^{5}$ This is not to be confused with a reader-response theory, which relies on the subjectivity of the reader as a guiding interpretive grid.

${ }^{6}$ In addition to the challenges mentioned earlier, Kamara was denied citizenship on the basis of his polygamy (Archives Nationales du Senegal $13 \mathrm{G} 6$ (17)), and his request for government support in his old age was denied (Pondopoulo 1993: 103).

${ }^{7}$ On Islamic hagiography, see the comprehensive view in Renard (2008; 2009) and Bashir (2011) for an approach that stresses the specificity of a given text.
} 
of classification and organization of knowledge, such work consciously or unconsciously becomes a task of modification and adaptation, a putting into relation of two terms that are not identical. ${ }^{8}$ This requires more than finding the equivalences of two genres; it demands the accommodation and negotiation of different modes of thought and representation. Translating tarjamatì (Kamara 2014: 1) as 'my biography', particularly as a mode of historical representation, is a treacherous act. That being said, the margin of difference between tarjama, tabshīr and tadhkira on the one hand and autobiography on the other furnishes the space to reflect upon the specificity - that is, the sameness and difference - of Kamara's work in relation to other similar texts in his trans-scalar context (local, regional, Islamic, discursive). Furthermore, that space allows us to consider Kamara's specificity in relation to now-hegemonic modes of thinking the human. It is in this margin that we might witness Kamara's subjectivity emerge.

The question of translation is particularly relevant in the consideration of subjectivity as the meaning of a life because of the dual semantic resonance in the term tarjama. Depending on the context, and particularly in the later period, tarjama might mean biographical profile or it might mean translation or interpretation. In the greater Maghreb, a space often thought to include the Western Sahel, tarjama was an especially important genre. It recorded the education, character, deeds and genealogies of the khass, or the special elite. Emulating the paradigmatic representation of a life found in the sira literature on the biography of the Prophet, such works presented the lives of those who similarly sought to emulate Muhammad, the ideal Islamic form of life. I propose that the interpretation of the excess of a life situated in history, translating it into the Islamic form of life that is beyond time or space and putting it in textual form, is the primary task of a tarjama such as Tabshīr.

Although classical historicist approaches have tended to avoid hagiographic texts, more nuanced social, cultural and religious histories have elaborated dynamic methods to read them in the context of Muslim West Africa (Babou 2007; Ngom 2016; Seesemann 2011; outside the African context, see also Bashir 2011: 18-20). By writing about his own life as a wati, Kamara streamlines what Bashir calls the hagiographic process, turning the work into an expression of his own subjectivity as a friend of God and offering us a unique opportunity to think about saintly subjectivity.

'I say,' Kamara writes in the introduction, 'one comes closer to the truth with what a person says about himself, even if the opposite is said' (Kamara 2014: 1). Directly after announcing his text as a self-authored hagiography, Kamara justifies his project by referring to other saintly figures who did the same. He names four authors and their works that might be considered autobiographical in nature. Two of these authors - the prolific early modern 'Abd al-Wahhāb alSha 'rānī (d. 1565) and the late medieval Ibn 'Ațā' Allāh (d. 1310) - are major figures in the tradition of global Sufi thought (Winter 1982; Makdisi 2012). The other two, Sidi Mukhtar al-Kunti (d. 1811) and Hajj Umar Tal (d. 1864), were among the most important religious and historic personalities of the eighteenth-

\footnotetext{
${ }^{8}$ The entire problematic in Vincent Cornell's important work on Islamic sainthood centres on the productive problem of translating the terms walaya and wilaya, the abstract noun form of the specific watt, as sainthood (Cornell 1998).
} 
and nineteenth-century Western Sahel (Robinson 1985; Syed 2017; Batran 2001; Marcus-Sells 2015). By including these four authors, Kamara locates himself simultaneously in West Africa and in the wider Islamic tradition. Kamara then cites two verses from Sura Mariam of the Qur'an, which suggests the importance of knowing when one is born, died and resurrected (Qur'an 19:15, 19:33). This opening justifies Kamara's writing about himself as a friend of God by invoking previous saintly figures while grounding such a potentially immodest act in the chief epistemological and legal authority of the Qur'an. Second, it entextualizes Kamara's status among some of the most prominent 'people of God'. Tabshīr plays an important part in the hagiographic process by representing Kamara's relation to the ideal Islamic form of life through emulation and proximity while authorizing it through sound knowledge.

Tabshir is not simply a narration of Kamara's life from beginning to end. In fact, only the first chapter might be said to be properly biographical, giving explicit details about his life experiences. The other chapters present titles and excerpts of previous works, testimonials to his knowledge and saintly character, and poetry devoted to him, as well as essays on the master-disciple relationship, insight about the nature of prayer not to be found in the authoritative sources of the law, and his famous critiques of genealogical manipulation by elites in the greater Western Sahel. What is important to Kamara is not so much his life as such, but the evidence that demonstrates that he - by proof of the knowledge he has acquired, the grace that he has been granted and the piety that he has practised - has achieved a special spiritual status. After arguing the superiority of spiritual genealogies over carnal ones, Kamara concludes the work by declaring that his own spiritual lineage goes back to the fourth khalif of Islam, 'Ali, often considered the father of Sufism. There is hardly a stronger claim than that. Reading Tabshīr only as biography offering objective facts misses such rich texture.

Among the most significant evidence for Kamara's status as a friend of God are his presentations of marvels, miraculous signs of his election. The title of the work is the verbal noun form of bishärat, which means good news, glad tidings or augurs, prophetic signs that indicate something of godly worth. In this case, the text is the presentation of Kamara's election as a friend of God. The most compelling signs are narrated in the opening chapters. One scene stands out in particular, as it serves to explain the major turning point in Kamara's life. The scene recounts a dream that Kamara had at around the age of twenty-one or twentytwo, when he had still been enjoying his youth with the frivolity associated with it. Then, everything changed:

I saw in a dream as if I had come to live in a house where the Prophet of God, our father Ibrahim, had appeared as my father in old age. I greeted him. He said to me: 'We thought that you were taking a path other than ours or you were taking a course that was not our course.' ... It was at that moment that the Messenger of God entered the room. Our father Ibrahim got off the bed and left without me knowing when or how, or much less where, to go. The Prophet sat down in the room next to the door facing me and asked: 'What did this man say to you?' I said that he said to me: 'You all think that I am taking the course of a path other than your own.' He started to reassure me, saying, 'You are safe. There is nothing wrong with you.' He continued to say this until I sensed that I faced him and he approached me. (Kamara 2014: 9-10) 
Kamara then informs the reader that he immediately stopped with the diversions of youth and sought out the person who would become his spiritual guide, Shaykh $\mathrm{Sa}$ 'ad Buh. He also sought out a dream interpreter who pronounced that people would bear Kamara as he had borne Ibrahim. From the dream itself, we see Kamara's close proximity to Muhammad. It is this closeness with and mirroring of Muhammad that is the basis of Kamara's subjectivity as a proximate embodiment of the ideal Islamic form of life.

Tabshīr can also be called a sentimental text, because it documents a number of Kamara's affective motivations in the twilight of his life. In the chapter on the praise he has received from 'elite scholars of action and righteous friends' of God, Kamara informs the reader of these motivations:

I had been having a lot of depression and dread, little joy and hopefulness ... However, a state of hope and delight ran over me. I said to myself, it would be better if I wrote glad tidings [bishärat] to strengthen my hope in God. So, I wanted to write here what I have left of the letters which contains praise for me. (Kamara 2014: 23)

Composed primarily of letters from his peers as well as colonial officials such as Henri Gaden (d. 1939) and Maurice Delafosse (d. 1926), the chapter documents that he was a consummate letter-writer. ${ }^{9}$ One pictures an ageing Kamara looking through his papers to remind himself of the support and enthusiasm with which he had been received over the course of his life. This passage and its sentimental excess offer a key to reading the broader text as a part of the hagiographic process. In collecting these letters and recollecting his own memories, Kamara is sincerely making sense of his life as a friend of God, someone who through emulation and proximity has a subjectivity that approaches the ideal Islamic form of life.

The subjectivist approach to Kamara corresponds to the way in which he has been remembered by his descendants. ${ }^{10}$ Stories of miraculous events, feats of perception and boasts of universal praise dominate their memory of him today. In one story, recounted to me by Kamara's grandson, Cheikh Saad Buh Kamara, a noted Mauritanian sociologist, Kamara spits on an earring that is then passed around to the women in the family. ${ }^{11}$ With the earring in their possession, the women had sons. Another story has Kamara's son Tourad asking his father for help in dealing with the colonial administration, after he had been accused of not speaking Arabic well enough to perform his role as a censor, reading Arabic texts and highlighting things that might be politically troublesome. Musa Kamara told his son how to handle the situation, and it was soon resolved. The point of that story was that Kamara had bașira, or insight into how things really work beyond what is

\footnotetext{
${ }^{9}$ The network of relationships documented in these letters has been referred to in Kamara studies as the 'cult of friendship' since Amar Samb's work. With the exception of Anna Pondopoulo's superb reconstruction of the saga of the translation of Zuhür by using Kamara's correspondence (Pondopoulo 1993), the letters have been used only superficially. The practices, materiality and sensibility of letter writing in Kamara's moment - the world the letters stand in for as a representation of a past since disappeared - warrants further reflection.

${ }^{10} \mathrm{As}$ far as I am aware, Pondopoulo is the first person in the scholarship to recognize the divergence of the scholarly reception and familial memory of Kamara (see Pondopoulo 1993: 100-1).

${ }^{11}$ Interview, Nouakchott, February 2017.
} 
apparent or visible, long an important characteristic of saintly figures in the region. This esoteric Kamara differs significantly from the objectivist reading of an enlightened Kamara, the Kamara of a Senegalese modernity inflected by race pride and religious identity, which I describe in the final section. The difference is not merely a question of what details are allowed as historical; rather, at stake are the meanings made and interpreted in ways that can be made objective for some other instrumental use.

\section{The objectivist reception of Kamara}

So far, I have argued that Kamara's life can be fruitfully read from a subjectivist point of view. However, until very recently, scholarship has tended towards objectivist readings of Kamara's work that might make him useful by yielding historical facts on a rationalist basis. This was as true in the late colonial period as it has been for the nationalist period. This objective mode accompanied the colonizing process that sought to order the world rationally - that is, by empirical observation and syllogistic logic, systematic thinking and instrumental reason. This process should not be described too euphemistically, as it was defined by a relation of violence and surveillance, and the boundary between knowledge and operational intelligence was a fuzzy one (de l'Estoile 2005: 30-57; Adedze 2003). As the colonial order became self-confident in its establishment, subjectivist modes of meaning-making were subordinated to the objectivist mode; this continued long after independence. This reception history of Kamara reflects key epistemological transformations relating to the hegemonic ways in which Islam has been understood in francophone Africa.

Since at least the 1850s, colonial administration in French West Africa differentiated bad Muslims from good Muslims according to who could be useful in achieving security in their territories, facilitating trade in the region, and garnering resources from metropolitan France to continue their mission. However, this practice of designation was largely haphazard, based as it was on the spectrum of relations defined at one end by the merchant and scholarly families who lived in the capital, Saint-Louis, and who worked hand in hand with the French, and at the other by groups remote from the coast who waged open conflict. ${ }^{12}$ However, by the inter-war period, colonial policy towards Islam became systematized through the establishment of institutions of surveillance, the development of a pragmatic sociology of Islam and the theorization of racial difference in Islam (Harrison 1988; Burke 2014; Marsh 2018: 24-34). These processes are often referred to as Islam noir; this differentiated black Muslims from Arab Muslims, along with their forms of religious practice and political orientation, on the basis of an inherent biological difference. In this schema, black Muslims in Africa could not be known from the great texts of the universal religion as the Orientalist position on Arabs had determined; only direct observation of

\footnotetext{
${ }^{12}$ This spectrum is effectively represented in the contrast between Bou el-Mogdad (d. 1880), the chief interpreter and advocate for the Muslim community in Saint-Louis (M'Bayo 2017: 39-46), and Hajj Umar Tal (d. 1864), a militant saintly figure whose messianic movement came into direct confrontation with colonial forces at Médine along the upper Senegal River in 1857 (Robinson 1985; Syed 2017; Marsh 2018: 96-131).
} 
empirical particularities in the twin forms of surveillance and ethnography would do. Extending Simone Browne's argument that blackness was subject to and the means by which surveillance was developed during the slave trade (Browne 2015), we can fruitfully understand surveillance as it took on Islam in the colonial context of French West Africa as being defined by similar biopolitical imperatives.

It is within this web of surveillance, knowledge production and policymaking that Kamara first appears as an object of surveillance and someone who might be useful as an instrument of governance or a source of empirical data. As early as 1912, Kamara appears in an article by Arnaud expressing criticism of abuses for material gain in the maraboutic system (Arnaud 1912: 122, cited in Pondopoulo 1993: 99). In 1914, he received recommendations from William Ponty (governor from 1908 to 1915), certifying his loyalty. Paul Marty's influential study of the personalities of Islam in Senegal also depicted Kamara's intelligence (Marty 1917: 29).

Alongside being subjected to surveillance, Kamara began to be seen as a potential source for a positivist history that could serve as the foundation of colonial knowledge. As Anna Pondopoulo has convincingly argued, Kamara should be situated within the development of colonial theory and practice of knowing and governing (Pondopoulo 1993: 98-9; 2008). Following the scholar Charles Monteil, who argued that colonial knowledge had to be based on the history, languages and customs of governed populations in order to effectively and efficiently achieve the administration's objectives, scholar-administrators Maurice Delafosse and Henri Gaden published several works either by or in conjunction with African authors (Soh 1913; Dyao 1912; Gaden 1931; Caam 1935). ${ }^{13}$ Recent scholarship has shown that the colonial state had developed significant networks of informants, schoolteachers and Muslim scholars who would provide what was coming to be understood as ethnographic knowledge in the form of texts. In addition to Kamara, two important examples were Yoro Dyao and Siré Abbas Soh, who may even have been in competition with Kamara in attracting resources to carry out research (Labrune-Badiane and Smith 2018: 218-26). Some of the most substantial work that Kamara undertook responded to a colonial demand for historical, ethnographic and Islamic legal knowledge. Zuhür al-Basātīn is the product of Kamara's attempt to satisfy the mix of orientalist textualism, historicism and empiricism upon which colonial governance might be based.

However, there was a degree of ambivalence as to just how useful such works would be. For instance, in his preface to Chroniques du Fouta by Siré Abbas Soh, Delafosse laments that the region had no equivalent of the major tarikhs, or historical chronicles, of the middle Niger, such as the one he had helped translate with his father-in-law, the noted orientalist Octave Hodas (Soh 1913; see also Schmitz 1998: 44-51). Delafosse said that Soh's text was of little historical value, but it gave a precious glimpse of a humanity in its infancy, thus adhering to common tropes of racist thought (Mudimbe 1988: 68). Although a 1931 decree inaugurated a literary prize for local works, for which Kamara would submit his hagiographic work on Hajj Umar Tal, by the end of the decade the epistemic chasm between the older orientalist paradigm that read texts and the newer

\footnotetext{
${ }^{13}$ On Delafosse, see Amselle and Sibeud (1998) and Delafosse (1976); on Gaden, see Dilley (2014).
} 
ethnological one that surveilled populations was too great; ${ }^{14}$ the work of translation between them had become too tedious, time-consuming and ineffective for the work of colonial governance.

By the late colonial period, Kamara and his work would be dismissed altogether. Referring to Kamara's Zuhūr al-Basātīn, the noted orientalist Vincent Monteil writes:

The content of the Arabic manuscript is quite characteristic of the rambling aspect of this kind of work. 866 recto-verso folios contain a vast compilation in which, in the greatest disorder, the author mixes his own knowledge with information gleaned from works sometimes difficult to identify ...

Nothing is therefore more disappointing than a reading of this kind of work, and it requires deciphering never-ending digressions to pull out some useful nugget of the text. They are books of sorcery (grimoires) that the Portuguese call alfarrabios: that is to say, 'gibberish'. (Monteil 1964: 12, 13) ${ }^{15}$

In just two paragraphs, Monteil summarizes and dismisses a mammoth work. He is able to do so because of the interpretive schemes of Islamologie, and the embedded assumptions inherent to the theory of Islam noir, which viewed the textual productions of Islam in Africa as virtually useless for the modern historian. By the early 1960s, when Monteil was writing, even French Orientalism had become far more empiricist in its orientation. As a specific iteration of philology, Islamologie was primarily concerned with origins and originality. ${ }^{16}$ Accordingly, Monteil read Kamara's text as a derivative work lacking an authorial voice. While the text resembled the Islamic tradition of letters with its Semitic script, under the theory of Islam noir, the blackness of its author rendered it into something not much more than the speech of barbarians.

However, Kamara would not be silenced forever. Taking up the terms of order and evaluation established by an objectivist Islamologie, Amar Samb, Senegal's first academic scholar of Islam, sought to recuperate Kamara as an empiricist and rationalist historian of the first rank. Samb's overall project can be described as an attempt to nationalize the Arabo-Islamic tradition and to modernize Senegalese Islam. In contrast to the colonial state's theorizing at the turn of the twentieth century, which had been preoccupied with isolating Muslim subjects in French West Africa from a newly self-aware global community, independence-era intellectual production was concerned with building the nation (Aydin 2017; Harrison 1988). In this moment, Samb's response to Monteil was to prove that not only was Kamara useful as a source for writing history, the explanatory mythological charter of the nation state, but he was a rigorous historian in his

\footnotetext{
${ }^{14}$ See also the work done by Labrune-Badiane and Smith on native teachers and the literary competition (2018: 234-8).

${ }^{15}$ As one of the reviewers of this article has pointed out, 'grimoire' is sometimes used figuratively to refer to a text that is graphically dark, difficult to read, or even arcane. Monteil's use of grimoire may be merely a benign statement about how difficult it is to read the text. Whichever way one takes this specific ambiguity, the relation between magic and difficulty of reading is relevant to the epistemological transformations that made the former a metaphor of the latter.

${ }^{16}$ For a critique of the monologism of older philological studies, see the superb introduction to Inden et al. (2000).
} 
own right. Samb writes of Kamara in the introduction to his translation of Kamara's book on 'Umar Tal:

His qualities as a historian are not difficult to demonstrate: it only suffices to browse his book on The Life of El-Hadji Omar. Starting with material testimony, written and oral, the Cheikh proceeds, armed with a critical sensibility, always with an eye for discerning the authentic from what is not, the natural cause of legend, and the rationally admissible facts of miracles ... [ He cites Kamara speaking about the spurious Umarian claim to Prophetic descent.] Such is the method of a real historian: that is to say, reasoning from real facts or from reliable information, or in the absence of the two, putting forward hypotheses that are not repulsive to a sane and rational explanation. (Samb 1972: 115, 116; 1974: 9-10)

For Samb, Kamara's self-conscious method puts him in a class of modern European historians in the tradition of Ranke, Carlyle and Le Bon. At the same time, Samb praises Kamara's style as representing 'the literary virtues that good Arab writers envy in Senegal' (Samb 1972: 116). But there is an underlying tension in Samb's interest in Kamara. On the one hand, Kamara represents an entire tradition of Arabic writing in Senegal, and his work puts this tradition on a par with European and Arab writing. On the other hand, Samb's preoccupation with finding an exceptionally great writer of a uniquely Senegalese tradition divorces Kamara from that tradition. Samb appears stuck between Romantic notions of the artist and his relationship to a tradition, a valorization of the Arabic language as a vehicle of nationalism, and an insistence on the need to develop tradition into something modern. We are left with an ambiguous assertion that it is only Kamara's Senegalese-ness that sets him apart from modern historians, but it is his rationalistic approach to history that puts him among their rank.

The traces of French Islamologie are clear in Samb's reading of Kamara. Beyond the references to French orientalists, which situate Samb's work in the field of Islamologie, his concern with identifying Kamara as a historian emerges as a primary criterion of evaluation. Kamara was a good historian because he was a positivist historian. Such a framing inevitably puts Kamara and his written production in the terms of European history.

Kamara's insights into how to think about Senegalese society, particularly his treatment of genealogy, have not been a major part of his reception (Kamara 2015); instead, Samb's Islamologie has rendered Kamara a source of information, and has reinforced Europe's place as the standard measure of what constitutes history. Samb achieves his goal of demonstrating a black contribution to the civilization of the universal (Senghor's civilisation de l'universel; Senghor 1964; 1977), but at what cost? As Samb announces in the preface to his first work, 'it is time to show the world what Negro genius is capable of producing in contact with a civilization, or a foreign culture' (1972: 7). However, in accepting the civilization concept, in saying that the 'Negro' has something to bring to civilization by way of its contribution to Arabo-Islamic heritage, Samb tacitly accepts the hierarchy in which Europe is on top, the Muslim world comes second, and the 'Negro' third. By using the very terms, conventions and methodologies of the so-called colonial sciences, Samb ensures the continued epistemological subordination of the formerly colonized world. Moreover, the process of literal and figurative translation necessarily eliminates those elements of Kamara's work that make it 
comprehensible on its own terms, and that could be the theoretical basis of a dynamic form of social inquiry in Senegal today.

The objectivist reading of Kamara, elaborated as it was over the course of the late colonial and nationalist periods, reflects a particular form of knowledge that sought to stabilize and render useful Kamara's texts as sources of information. This form of knowledge was marked by the contest and transitions between a French orientalist paradigm and a positivist ethnographic one. It is somewhat ironic that the valorization of Kamara in the nationalist period followed so closely the methodological problematic of colonial knowledge while attempting to offer different thematic arguments. However, such ironies continue in emergent readings that seek to valorize Kamara as a Muslim scholar-saint.

\section{Emergent horizons for reading Kamara}

As an on-air discussion during the summer of 2014 about the Israeli occupation of Palestine descended into an exchange of verbal fire, Tariq Ramadan, a once-major figure of global Islam who has since fallen from grace following accusations of sexual assault, launched the worst insult imaginable for today's African intellectual: he accused Bakary Sambe, a Senegalese professor of Islamic studies and a visible public intellectual, of having a colonized mind. At a momentary loss for words, Sambe hit back at Ramadan, saying, 'It is you who are the first colonizers, you Arabs.' Once tempers cooled, Sambe wrote on his blog to clarify the statement that solicited Ramadan's insult (Sambe 2014). He spoke from neither Paris nor Washington, as Ramadan had suggested, but from Ganguel, a small village on the left bank of the middle Senegal River. This small place, connected by a long, rough dirt road, is a far cry from the centres of Françafrique and the New World Order. Yet, for Sambe, it symbolized an autonomous tradition of enlightened, modern Islam - an Islam that was peaceful, tolerant and learned - because it was the long-time home of Shaykh Musa Kamara. Sambe's invocation of Kamara as the embodiment of an autonomous, enlightened Islam follows a history of intellectual projects in Senegal that have sought to reconcile Islam, liberalism and an African identity in order to shape a uniquely Senegalese modernity in step with the rest of the world (Seck 2010). This reconciliation has been required to make Islam in Senegal fit within the modern measures of religion as individual private belief and practice. Since at least 2013, when a major conference was convened by the Islamic Institute of Dakar, this once marginalized figure has re-emerged as an important reference for thinking history, Islam and the modern in Senegal (Majla al-dirāsāt 2014). Kamara's re-emergence, however, has been characterized by a convergence of rationalist and subjectivist readings institutionalized by a secularist framing of Islam as a modern religion.

Kamara is an especially attractive figure for Senegalese intellectuals - secularist and Islamist alike - to do things with because the multiple and contradictory receptions of him encourage a discourse that operates simultaneously in multiple and contradictory registers. Kamara, in his writing and in the memory of him, is legible to both the rationality of the state and the spirituality of society.

Such ambiguity is operative in the context of making arguments within a discursive context of African Islamic modernity, in which African identities, Islamic forms of life and political liberalism have long coexisted in conflict and 
collaboration. ${ }^{17}$ This problem space is often captured in shorthand by the invocation of the 'Senegalese exception'. ${ }^{18}$ Bakary Sambe's comments after his encounter with Ramadan illustrate how effective mobilizing the figure of Kamara can be within the space of signification of this African Islamic modernity. Sambe wrote on his website:

At the end of the debate, inspired especially by Cheikh Ahmadou Bamba, Cheikh El Hadji Malick and Cheikh Moussa Camara in my critique of jihadism and violence in the name of Islam, I reaffirmed that in Africa we have the appropriate resources for Islamic religious discourse and have no need to be Muslims supervised by others. (Sambe 2014)

By referring to three notable saintly figures from Senegal, Sambe identifies an autonomous tradition that provides resources for and examples of the African nation praised for both its exceptional democratic values and its membership in the larger world of Islam. ${ }^{19}$ This rhetorical move extends Sambe's claims from equality to superiority, on the basis of a tradition that resembles liberaldemocratic values. Kamara's intellectual output enables the rejection of the globally hegemonic view that, in Islam - as in all matters - Africa is derivative, unlearned and dependent on others, and asserts that the history of African Muslims has a unique value for modernity, a newer term for the Senghorian civilization of the universal.

At present, the public register of discourse concerning Kamara, in Senegal and beyond, tends to revolve around those elements and material in his oeuvre that appeal to modern, rationalist, liberal-democratic values. Typically mentioned are his critical position on violence, his ecumenicalism, and his maintenance of a pious distance from political power. The critique of jihad has had a particular purchase. In Akthar al-Rāghibīn fì al-jihād (Kamara 2003), Kamara argues that jihad is not an acceptable practice because of the loss of innocent lives and a lack of prophetic leadership to authorize it. This text is familiar to a Senegalese audience mostly because of Amar Samb's translation, entitled 'Condamnation de la guerre sainte' (Samb 1976). ${ }^{20}$ The immediacy of the threat posed by political violence makes Kamara's arguments critical in the sense that they respond to a present crisis in which the scale of the militarization of the Western Sahel is as great as it has been since it was occupied by the French military during the

\footnotetext{
${ }^{17}$ David Scott's use of 'problem space' has been most useful in thinking about this (see Scott 1999; 2004: 4).

${ }^{18}$ Both inside and outside the country, the explanation for why Senegal is the exception to the African and Muslim rule is the presence of Sufi Islam, a tradition of mysticism institutionalized in religious orders. Recognized as 'good Muslims' as opposed to 'bad' Salafi ones, Sufis - and, by extension, the Senegalese state - have been viewed as dependable partners in the global War on Terror. In many ways, the discourse of the Senegalese exception harkens back to the colonial discourse about the racial particularity of black Islam.

${ }^{19}$ On the role of Islam in the 'Senegalese exception', see Diouf (2013) and Ralph (2015).

${ }^{20}$ As Mbaye Lo has pointed out, Samb's translation of this work as 'Condemnation of Holy War' is incorrect from the perspective of Islamic scholarship. To condemn something is a much higher degree of disapproval that requires a certainty that Kamara likely avoided claiming. Instead, he 'invalidated' the use of jihad, claiming not that it was unacceptable trans-historically, but that for his context it was no longer valid (Lo 2016).
} 
colonial period. The post-2013 appropriation of Kamara's argument is decontextualized and stripped of its meaning within its own problem space in order to be mobilized as modern critique. That such a timely argument is made in Islamic terms against Islamist violence by a Senegalese thinker makes claims against Arab paternalism and imperialism, like those voiced by Bakary Sambe, possible and compelling.

Kamara's views on the relationship between the major monotheistic religions are also often used to explain and justify a popular Senegalese discourse on ecumenicalism and tolerance. Any visitor to Senegal today will likely encounter a discourse about how religiously open the country is; how, despite religious differences, the Senegalese people are united by some underlying strata of cultural practices - even the first president, Léopold Senghor, was Catholic while the majority of the population is Muslim. These same discourses are echoed globally in various representations of Senegal's exceptionalism. During my stays in Senegal, Kamara's speech delivered at the opening of the Cathédrale du Souvenir in Dakar in 1935 (Kamara 1973, also translated by Amar Samb) was often referenced. The use of Kamara's texts gives Senegalese modernity scholarly legitimacy, while providing the ideology of tolerance its historical authenticity.

Further, Kamara's pious distance from politics is often taken as a normative model for the relationship between religion and politics. Today, the Kamara family insists that their forefather had no interest in politics, that he was part of a quietist tradition. ${ }^{21}$ This position, also emphasized by academics, would seem to be confirmed by Kamara's own account of himself in his Tabshīr, as Amar Samb has argued (Samb 1972: 128): Kamara could have been an inspector of Arabic instruction, or a Muslim judge, and yet he decided to stay in his small village to cultivate the land, teach the Qur' an, and devote himself to God. Such a representation is often accompanied by a criticism of contemporary religious leaders who appear too interested in political power and accumulating wealth. While this representation might very well be true, what is most interesting is how smoothly it coheres with the liberal-democratic premium placed on the separation of religion and politics, and how it offers itself as a normative measure against which to judge people today.

In sum, Kamara is made to be a key symbolic and substantive resource by which a Senegalese modernity can be articulated. This alternative modernity is both distinct from and compatible with global political modernity, an AfricanIslamic liberalism of which a 'good' public Islam is considered the source, beyond the influence of the West or the experience of colonialism. Kamara is an attractive figure for such a liberalizing project because his example seems to encourage the type of political structures and relationships palatable to liberal democracy: tolerance, pious distance of religion from the state, and the controlled exercise of reason. At the same time, he gives the unique and specific cultural content needed to make modernity in a Senegalese image. In short, new readings of Kamara have permitted the formulation of a secular Islam.

Kamara is no longer only a figure who is useful, whether as an informant (as was the case for the French) or as a historian (as was the case for Samb).

\footnotetext{
${ }^{21}$ Elsewhere this tradition has been described as the Suwarian tradition in West African Islam (Sanneh 2016).
} 
He becomes an example and a resource to define and objectify 'religion' in the Muslim-majority country. It is in his saintliness, his esoterism, and so on, that a particular theory of what religion is, what it should do and how it should be in the world is stabilized. This is in fact a secularized, or a post-secular, version of 'religion' that is being endogenized - made out to be a phenomenon that was already present before colonial rule, through the example of Kamara. ${ }^{22}$ But in addition to the changing representations of Kamara that I have analysed so far, attention to the discursive practices - that is, the doing things with words, the institutional configurations that condition those performances, and the processes of authorization of acceptable speech - that has been directed towards him offers a perspective on the singularly historical nature of the emergent horizons for reading Kamara. Where, for example, the university and its Institut Fondamental d'Afrique Noire was the site of knowledge production on Islam in Senegal during the nationalist period, the location of authorized discourses has shifted to the Islamic Institute of Dakar, which is attached to the city's central mosque, a quintessentially public religious institution. This institute has since established an Islamic studies journal in which a translation and summary of Kamara's critique of jihad figured prominently alongside institutional histories of Islamic studies in Senegal (Kamara 2013). In short, at the very least there has been a change in where the authority to speak about Kamara formally is invested. Whereas the university spoke of Kamara's historicity, the new location of speech on Kamara pronounces on his religiosity. The resulting representation becomes Kamara the scholar-saint.

Again, the emergent discursive practices and representations of Kamara are critical at a moment in which the horizon of militant jihad makes the contest of defining religion of the highest political order. The development of a religious Kamara integrates a utilitarian and instrumentalist theory of knowledge that has sought to objectify Islam with an Islamic subjectivity in the form of secular religion. However, this integration is not one of reconciliation with the global hegemonic order, as the narrative of the Senegalese exception might suggest. Rather, the empiricist mode, along with its instrumental logic of statecraft, subordinates Islamic subjectivity into objective frameworks, thereby limiting the possibilities of the Islamic as demanded by liberalism.

\section{Conclusion}

In this article, I have argued that the prolific Muslim intellectual from colonial-era Senegal Shaykh Musa Kamara is a canonical figure, and that the multiple readings of his life embody the entanglements of Africa, Islam, colonial modernity and ongoing forms of domination that we might characterize as global liberalism. Starting with his auto-hagiographic Tabshīr, I elaborated a subjectivist mode of reading Kamara that sought the textures of his writing and the affective and

\footnotetext{
${ }^{22}$ I thank Sean Hanretta for the framing of 'endogenization'. Of course, I am not saying that 'religion' is new, but that the institutions, resources and practices devoted to defining and policing what is good and bad religion find a more concrete expression and have consequences for the ways in which intellectual resources such as Kamara might be thought.
} 
spiritual dimensions of his experience that are beyond historical reconstruction. In this reading, Kamara appears as a Muslim friend of God who, through proximity to and emulation of Muhammad, the ideal Islamic form of life, achieved a saintly subjectivity. I then traced attempts to objectify Kamara's writings as sources of information or as historical consciousness. During the colonial period he was viewed, depending on the shifting criteria applied, as a more or less valuable informant. During the nationalist period, he appeared as an essential African voice of a non-colonial history. Finally, I explored the emergent readings of Kamara in which he becomes the symbol of Islam in Senegal as a modern, secular religion. In this reading, which is characterized by a problem space partly structured by the threat of Islamist political violence in the region after 2013, Kamara appears as a composite scholar-saint, someone who satisfies the spirituality of society while remaining legible to the rationality of the state.

If I have identified a plurality of readings of Kamara, it is not to measure one against the other to find the one that is most accurate, the most true. Instead, I have aimed to identify the different horizons that inform different readings and to insist, in fact, on the necessity of the act of reading and of holding all at once a multiplicity of interpretation. Doing so insists upon, for lack of a better term, a humanistic but critical attitude towards the past and to future possibility. This is a textual attitude that Kamara himself exemplified in his own intellectual practice of travelling, speaking to people, asking them questions and judging their replies. It is an attitude cultivated by broad and deep reading, curiosity and reflection on matters both mundane and ephemeral. In a moment in which universitybased academics interested in Africa seek out decolonial approaches to thinking Africa, it is worth asking: what would it mean to think with people from Africa's past as resources for theory as opposed to sources of information? While Kamara's method is far from being institutionalized, the elaboration of a social inquiry that emerges from African historicities such as Kamara's will have to be as ambitious as it is imaginative. It will also have to reconstruct its own coloniality even as it stretches creatively to get beyond it.

\section{Acknowledgements}

Research for this article has been supported by the Ford Foundation and the Buffett Institute for Global Studies. I would like to thank Rebecca Faulkner, Sean Hanretta and Jonathan Adjemian for their comments as well as participants of the Institute for Research in African American Studies Conversations series and the Ifriqiyya seminar at Columbia University for feedback on an early iteration of this article. I am also grateful for the comments by the reviewers of this article.

\section{References}

Adedze, A. (2003) 'In the pursuit of knowledge and power: French scientific research in West Africa, 1938-65', Comparative Studies of South Asia, Africa and the Middle East 23 (1-2): 335-44. 
Al-Naqar, 'U. (1972) The Pilgrimage Tradition in West Africa: an historical study with special reference to the nineteenth century. Khartoum: Khartoum University Press.

Amselle, J.-L. and E. Sibeud (1998) Maurice Delafosse. Entre orientalisme et ethnographie: l'itinéraire d'un africaniste (1870-1926). Paris: Maisonneuve et Larose.

Arnaud, R. (1912) L'Islam et la politique musulmane francaise en Afrique-occidentale française. Paris: Comité de l'Afrique Française.

Aydin, C. (2017) The Idea of the Muslim World: a global intellectual history. Cambridge MA: Harvard University Press.

Babou, C. A. (2007) Fighting the Greater Jihad: Amadu Bamba and the founding of the Muridiyya of Senegal, 1853-1913. Athens OH: Ohio University Press.

Barry, B. (1998) Senegambia and the Atlantic Slave Trade. Cambridge: Cambridge University Press.

Bashir, S. (2011) Sufi Bodies: religion and society in medieval Islam. New York NY: Columbia University Press.

Bathily, A. (1970) 'Mamadou Lamine Dramé et la résistance anti-impérialiste dans le Haut-Sénégal (1885-1887)', Notes Africaines 125: 20-32.

Batran, A. (2001) The Qadiryya Brotherhood in West Africa and the Western Sahara: the life and times of Shaykh al-Mukhtar al-Kunti (1729-1811). Rabat: Université Mohammed V, Institut des Études Africaines.

Bousbina, S. (1992) 'Musa Kamara, un savant "autodidacte”, Islam et Sociétés au Sud du Sahara 6: 75-81.

Browne, S. (2015) Dark Matters. Durham NC: Duke University Press.

Burke, E. (2014) The Ethnographic State: France and the invention of Moroccan Islam. Oakland CA: University of California Press.

Caam, M. A. (1935) La vie d'el Hadj Omar, qacida en poular. Paris: Institut d'Ethnologie.

Cornell, V. J. (1998) Realm of the Saint: power and authority in Moroccan Sufism. Austin TX: University of Texas Press.

Delafosse, L. (1976) Maurice Delafosse, le Berrichon conquis par l'Afrique. Paris: Société Française d'Histoire d'Outre-mer.

de l'Estoile, B. (2005) 'Rationalizing colonial domination: anthropology and native policy in French-ruled Africa' in B. de l'Estoile, F. Neiburg and L. Sigaud (eds), Empires, Nations, and Natives: anthropology and statemaking. Durham NC: Duke University Press.

Dilley, R. (2014) Nearly Native, Barely Civilized: Henri Gaden's journey through colonial French West Africa (1894-1939). Leiden: Brill.

Diop, A. M. (2014) 'La vie et l'oeuvre de Cheikh Moussa Kamara de Ganguel (1864-1945)'. PhD thesis, Université de Cheikh Anta Diop.

Diouf, M. (2013) 'The public role of the "good Islam": Sufi Islam and the administration of pluralism' in M. Diouf (ed.), Tolerance, Democracy, and Sufis in Senegal. New York NY: Columbia University Press.

Dyao, Y. (1912) Légendes et coutumes sénégalaises. Cahiers de Yoro Dyao, publiés et commenté par Henri Gaden. Paris: Ernest Leroux.

Fisher, H. (1970) 'The early life and pilgrimage of Al-Hājj Muhammad Al-Amīn the Soninke (d. 1887)', Journal of African History 11 (1): 51-69.

Gaden, H. (1931) Proverbes et maximes peuls et toucouleurs: traduits, expliqués et annotés. Paris: Institute d'Ethnologie. 
Hanson, J. H. (1996) Migration, Jihad, and Muslim Authority in West Africa: the Futanke colonies in Karta. Bloomington IN: Indiana University Press.

Harrison, C. (1988) France and Islam in West Africa. Cambridge: Cambridge University Press.

Hilliard, C. (1977) 'The formation of the Islamic clerisy of the middle valley of the Senegal River, c. 1670-c. 1770'. PhD thesis, Harvard University.

Inden, R., J. S. Walters and D. Ali (2000) Querying the Medieval: texts and the history of practices in South Asia. Oxford: Oxford University Press.

Kamara, M. (n.d.a) Kāda al-itifiaq wa-l ilti'ām an yakuna bayna dīn al-Nașāra wa dìn al-Isläm [The Mending and Almost Coming Together of the Religion of Christianity and the Religion of Islam]. Translated by Samb as 'L'Islam et le christianisme'. Cahier 16. Dakar: Institut Fondamental d'Afrique Noire.

Kamara, M. (n.d.b) Al-fajr al-șādiq bi-al-nūr fì jawāb 'an masā'ila fiqhiyya fi 'adat al Füta Tür [The Trustworthy Dawn of Light in Response to the Legal Issues in the Customs of Futa Toro]. Cahier 14. Dakar: Institut Fondamental d'Afrique Noir.

Kamara, M. (1973) 'L'islam et le christianisme', Bulletin de l'Institut Fondamental d'Afrique Noire, Série B: Sciences Humaines 35 (2): 269-322.

Kamara, M. (1998) Florilège au jardin de l'histoire des noirs: Zuhûr al-basâtîn (avec une introduction de Jean Schmitz). Translated by S. Bousbina. Paris: CNRS Éditions.

Kamara, M. (2001) Ashhā l- 'ulūm wa-ațayab al-khabar fì sīrat al-Hāijj 'Umar [The Most Delicious of Sciences and the Tastiest of the News in the Biography of Hāijj 'Umar]. Rabat: Ma'had al-Dirāsāt al-Ifrīqīya.

Kamara, M. (2003) Akthar al-rāghibīn: fì al-jihād ba 'd al-nabì ìn man yakhtāru alzuhūr wa-malaka al-bilād wa-lā yubāt̄ bi-man halaka fì jihādihi min al- ‘ibād [Those Who Want Jihad the Most after the Prophets Are the Ones Who Choose Prevailing and Dominion of the Land and Who Do Not Care Who Perishes in His Jihad from among the People]. Rabat: Ma'had al-Dirāsāt alIfrīqīya.

Kamara, M. (2013) 'Aktar ar-rāgibīn: fī al-jihād bac'da an nabiyyina man yakhtāru az-zuhūr wa-mulk al bilād wa lā yubālī bi man halaka fì jihādihi min al- 'ibād', Revue d'Études Arabes et Islamiques 1: 139-59.

Kamara, M. (2014) Tabshīr al-khā' if al-hayrān wa tadhkīruhu bisā 'at rahmat Allah al-Karīm al-Mannān [The Spreading of the Good News of the Fearful and Confused and his Reminder of the Broadness of the Mercy of God, the Generous, the Bestower]. Dakar: Islamic Institute of Dakar.

Kamara, M. (2015) Al-Majmū' al-nafiss sirran wa 'alāniyya fì dhikr ba'd al-sādāt al-bīdāniyya wa al-fulāniyya [The Precious Collection of Secrecy and Publicity in the Memory of Some of the Bị̄̂ān and Fulani Nobles]. Rabat: Manshūrāt al-Zaman.

Labrune-Badiane, C. and É. Smith (2018) Les hussards noirs de la colonie: instituteurs africains et petites patries en Afrique Occidentale Française. Paris: Karthala.

Lo, M. (2016) “"The last scholar": Cheikh Moussa Kamara and the condemnation of jihad by the sword'. Available at <https://tirnscholars.org/2016/04/23/ the-last-scholar-cheikh-moussa-kamara-and-the-condemnation-of-jihad-by-thesword/index.html>, accessed 8 August 2017. 
Majla al-dirāsāt al-'arabiyya wa Islāmiyya (2014) Waqā 'i al-multqā al- 'ilmī hawl hayāt wa 'āmal al-shaykh Mūsā Kamara. Proceedings of conference on Shaykh Musa Kamara, 13 July 2013. Dakar: Islamic Institute of Dakar.

Makdisi, G. (2012) 'Ibn 'Ațā' Allāh' in P. Bearman, T. Bianquis, C. E. Bosworth, E. van Donzel and W. P. Heinrichs (eds), Encyclopaedia of Islam. Second edition. Leiden: Brill < http://dx.doi.org/10.1163/1573-3912_islam_SIM_3092>, accessed 24 July 2019.

Marcus-Sells, A. (2015) 'Realm of the unseen: devotional practice and Sufi authority in the Kunta community'. PhD thesis, Stanford University.

Marsh, W. (2018) 'Compositions of sainthood: the biography of Hajj Umar Tal by Shaykh Musa Kamara'. PhD thesis, Columbia University.

Marty, P. (1917) Études sur l'Islam au Sénégal. Paris: Ernest Leroux.

M'Bayo, T. (2017) Muslim Interpreters in Colonial Senegal, 1850-1820: mediations of knowledge and power in the lower and middle Senegal River Valley. London: Lexington Books.

Monteil, V. (1964) L'islam noir. Paris: Éditions du Seuil.

Mudimbe, V. Y. (1988) The Invention of Africa. Bloomington IN: Indiana University Press.

Ngom, F. (2016) Muslims Beyond the Arab World: the odyssey of 'Ajamī. New York NY: Oxford University Press.

Pondopoulo, A. (1993) "Une traduction "mal partie" (1923-1945): le "Zuhur al-basatin" de cheikh Moussa Kamara', Islam et Sociétés au Sud du Sahara 7: 95-110.

Pondopoulo, A. (2008) Les Français et les Peuls: l'histoire d'une relation privilégiée. Paris: Les Indes Savantes.

Ralph, M. (2015) Forensics of Capital. Chicago IL: University of Chicago Press.

Renard, J. (2008) Friends of God: Islamic images of piety, commitment, and servanthood. Berkeley CA: University of California Press.

Renard, J. (ed.) (2009) Tales of God's Friends: Islamic hagiography in translation. Berkeley CA: University of California Press.

Robinson, D. (1975a) 'The Islamic revolution of Futa Toro', International Journal of African Historical Studies 8: 185-221.

Robinson, D. (1975b) Chiefs and Clerics: Abdul Bokar Kane and Futa Toro 18531891. Oxford: Oxford University Press.

Robinson, D. (1985) The Holy War of Umar Tal: the Western Sudan in the midnineteenth century. Oxford: Oxford University Press.

Robinson, D. (1988) 'Un historien et anthropologue sénégalais: Shaikh Musa Kamara' [A Senegalese historian and anthropologist: Shaikh Musa Kamara], Cahiers d'Études Africaines 109: 89-116.

Robinson, D. (1998) "French "Islamic" policy and practice in late nineteenthcentury Senegal', Journal of African History 29 (3): 415-35.

Samb, A. (1972) Essai sur la contribution du Sénégal à la littérature d'expression arabe. Dakar: IFAN.

Samb, A. (1974) La vie d'El-Hadj Omar. Dakar: Hilal.

Samb, A. (1976) 'Condamnation de la guerre sainte par Cheikh Moussa Kamara', Bulletin de l'Institut Fondamental d'Afrique Noire, Série B: Sciences Humaines 38 (1): 158-99.

Sambe, B. (2014) 'African Muslims and international affairs: the hidden part of my debate with Tariq Ramadan', 1 September < http://bakarysambe.unblog.fr/ 
2014/09/01/african-muslims-and-international-affairs-the-hidden-part-of-mydebate-with-tariq-ramadan/>, accessed 8 August 2017.

Sanneh, L. (2016) Beyond Jihad: the pacifist tradition in West African Islam. New York NY: Oxford University Press.

Schmitz, J. (1998) 'Introduction' in M. Kamara (ed.), Florilège au jardin de l'histoire des noirs: Zuhûr al-basâtîn (avec une introduction de Jean Schmitz). Translated by Saïd Bousbina. Paris: CNRS Éditions.

Schmitz, J. and M. B. Lo (2016) 'Actualité de Cheikh Moussa Kamara (18641945): du Zuhûr à la critique du jihad'. Unpublished manuscript, 20 November.

Scott, D. (1999) Refashioning Futures: criticism after postcoloniality. Princeton NJ: Princeton University Press.

Scott, D. (2004) Conscripts of Modernity: the tragedy of colonial enlightenment. Durham NC: Duke University Press.

Seck, A. (2010) La question musulmane au Sénégal: essai d'anthropologie d'une nouvelle modernité. Paris: Karthala.

Seesemann, R. (2011) The Divine Flood: Ibrāhìm Niasse and the roots of a twentieth-century Sufi revival. New York NY: Oxford University Press.

Senghor, L. S. (1964) Liberté 1: Négritude et humanisme. Paris: Éditions du Seuil. Senghor, L. S. (1977) Liberté 3: Négritude et civilisation de l'universel. Paris: Éditions du Seuil.

Soh, S. A. (1913) Chroniques de Foûta sénégalais. Paris: Ernest Leroux.

Syed, A. (2017) 'Al-Hājj 'Umar Tāl and the realm of the written: mastery, mobility, and Islamic authority in 19th century West Africa'. PhD thesis, University of Michigan.

Ware, R. (2014) The Walking Qur'an: Islamic education, embodied knowledge, and history in West Africa. Durham NC: University of North Carolina Press.

Winter, M. (1982) Society and Religion in Early Ottoman Egypt: studies in the writings of 'Abd al-Wahhāb al-Sha 'rānī. New Brunswick NJ: Routledge.

\begin{abstract}
The colonial-era Senegalese Muslim intellectual Shaykh Musa Kamara is best known for his over 1,700-page Arabic-language text about the history and social organization of the greater Western Sahel, Zuhūr al-basātīn fì tārīkh alSawādin (Flowers in the Gardens in the History of the Blacks). Long celebrated by nationalist historiography as proof of an autochthonous historical consciousness and a spirit of tolerance, his status as a point of reference has been renewed in the contemporary context of Islamist political violence in the region. However, these receptions do not account for Kamara's own intellectual project, nor do they exhaust the possible readings of him in the present. In addition to thinking about Senegal in terms that cohere with the modern, Kamara also offers a way of thinking about the Muslim-majority West African country, and the greater Western Sahel more generally, in terms that have emerged from the historical specificity of the region. These include saintly subjectivity, notions of power irreducible to either the religious or the political, and a method of genealogical criticism. Importantly, he developed these ideas at the moment when a consensus about the place of Islam in colonial governance was being elaborated. Revisiting his body of work permits us to consider an analytical language about an African society with deep histories of Islam and an intellectual elaboration that was expressed within and sought to intervene in a colonial context.
\end{abstract}




\section{Résumé}

Shaykh Musa Kamara, intellectuel musulman sénégalais de l'ère coloniale, est surtout connu pour son texte de plus de 1700 pages rédigé en langue arabe intitulé Zuhūr al-basātīn fì tārīkh al-Sawādīn (Florilège au jardin de l'histoire des Noirs), qui traite de l'histoire et de l'organisation sociale du grand Sahel occidental. Salué depuis longtemps par l'historiographie nationaliste comme la preuve d'une conscience historique autochtone et d'un esprit de tolérance, son statut de point de référence a connu un renouveau dans le contexte contemporain de violence politique islamiste dans la région. Cependant, cet accueil n'explique pas le projet intellectuel de Kamara, et n'épuise pas non plus les lectures que l'on peut faire de lui aujourd'hui. Outre une réflexion sur le Sahel dans des termes en cohérence avec le moderne, Kamara offre également un mode de réflexion sur le grand Sahel occidental en général, et sur le Sénégal en particulier, dans des termes qui ont émergé de la spécificité historique de la région. Parmi eux figurent la subjectivité sainte, des notions de pouvoir qui ne peuvent se réduire au religieux ou au politique, et une méthode de critique généalogique. Surtout, il a développé ces idées au moment où un consensus sur la place de l'islam dans la gouvernance coloniale était en cours d'élaboration. Revenir sur son œuvre nous permet d'examiner un langage analytique concernant une société africaine riche en histoires profondes de l'islam et une élaboration intellectuelle qui s'exprimait intérieurement et cherchait à intervenir dans un contexte colonial. 